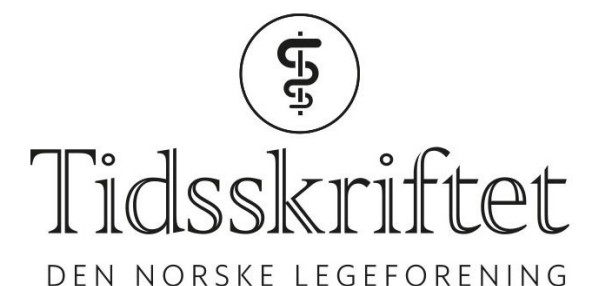

DEN NORSKE LEGEFORENING

\title{
Urin har vært brukt til så mangt
}

MEDISINSK HISTORIE

\section{SVERRE MYREN-SVELSTAD}

E-post: s@myren-svelstad.no

Avdeling for nevrologi og klinisk nevrofysiologi

St. Olavs hospital

og

Institutt for nevromedisin og bevegelsesvitenskap

Norges teknisk-naturvitenskapelige universitet

Sverre Myren-Svelstad (f. 1986) er lege i spesialisering i nevrologi og stipendiat.

Forfatter har fylt ut ICMJE-skjemaet og oppgir ingen interessekonflikter.

\section{JOSTEIN HALGUNSET}

Institutt for laboratoriemedisin, barne- og kvinnesykdommer Norges teknisk-naturvitenskapelige universitet Jostein Halgunset (f. 1951) er lege og professor i anatomi. Forfatter har fylt ut ICMJE-skjemaet og oppgir ingen interessekonflikter.

Urinen har vært oppfattet som både nyttig og unyttig og som ren og uren. Denne væsken har i lange tider vært del av diagnostikk og behandling, men har også hatt bruksområder utenfor medisinsk praksis.

Ordet urin skal ha kommet inn i de fleste vesteuropeiske språk fra det latinske urina, som er beslektet med greske oũ pov og har grunnbetydningen væske eller vann (1). Mens den språklige roten både på gresk og latin ble brukt til å betegne væske som renner ut av kroppen, har den nedarvede varianten på norsk også gitt opphav til en betegnelse for vann som drypper ned fra luften, nemlig yr (1). Islendingene har tilsvarende úrkoma, som betyr nedbør (2).

Imidlertid er islandsk et av de få germanske språkene som ikke har adoptert urin $\mathrm{i}$ betydningen kroppsekskret. De benytter i stedet betegnelsene pvag eller hland. På norsk gjenfinnes tvag, som betyr vask eller hett vann, i og med at urin ble brukt til å fremstille lut til vasking. Fra tvag har man avledet verbet tvcette = vaske, som på svensk altså heter tvätta (3). Dessuten er det nok lite kjent at ordet land også kan ha betydningen urin, og det brukes da om urin fra husdyr. Opprinnelsen til uttrykket er usikkert (4).

I dagligspråket finnes ulike varianter av ord som har med vannlating å gjøre. Disse ordene inneholder typisk en s-s-s-lyd, som en malende beskrivelse av den lyden vi hører når urinen spruter eller sildrer. Den vanligste varianten har vi fått fra det franske verbet pisser, som har spredt seg til mange europeiske språk, med litt ulike uttalevarianter.

En eldre, hjemlig betegnelse er mige, en slektning av det latinske mingere, som vi finner igjen i det medisinske fagspråket som substantivet miksjon (1). I Skáldskaparmál forteller Snorre Sturlason at jotnene laget en kjempe av leire, Mökkurkalfi, som skulle være så stor og sterk 
at han kunne vinne over Tor i tvekamp. Men det gikk ikke likere enn da de to møttes, sviktet motet hos kjempen: «svá er sagt at hann meig, er hann sá Pór» (5).

Mange andre betegnelser på å urinere har en typisk forskjønnende karakter, som «late vannet», "gå attom nova» (av nov = utvendig hjørne på hus) og "slå lens» (egentlig "tømme en skute for vann»)(6-8). Og om de gangene det går galt, har vi hørt uttrykket «bli våt i benklærne».

\section{Å kvitte seg med urin}

Når man før i tiden lot vannet ute i naturen, måtte man passe godt på hvor og hvordan det gikk for seg. Mange steder skulle man spytte før man gjorde det, for å varsle de underjordiske (9). Hvis man ikke varslet, kunne man få alvgust, altså elveblest - et uttrykk som kom av at man mente alvenes pust («blåst») var sykdomsførende og ga utslett. Andre steder ville det bli regn om man lot vannet ofte, eller oppholdsvær dersom to pisset i kors.

Man kunne bli migstam, få problemer med å late vannet, om man tisset i en bekk. For å få fart på vannlatingen brukte man ofte vanndrivende urter, gjerne avkok av persille og kjerringrokk. Krekling - også kalt migbær - skal fortsatt være i bruk (10).

Nattpotten ble vanlig da folk bosatte seg i tettsteder og landsbyer. Fra senmiddelalderen finnes det malerier og tresnitt med potte under sengen. Ut på 1700-tallet ble tinn- og leirpotter erstattet av fajanse, porselen og engelsk steintøy (fig 1) (11,12).

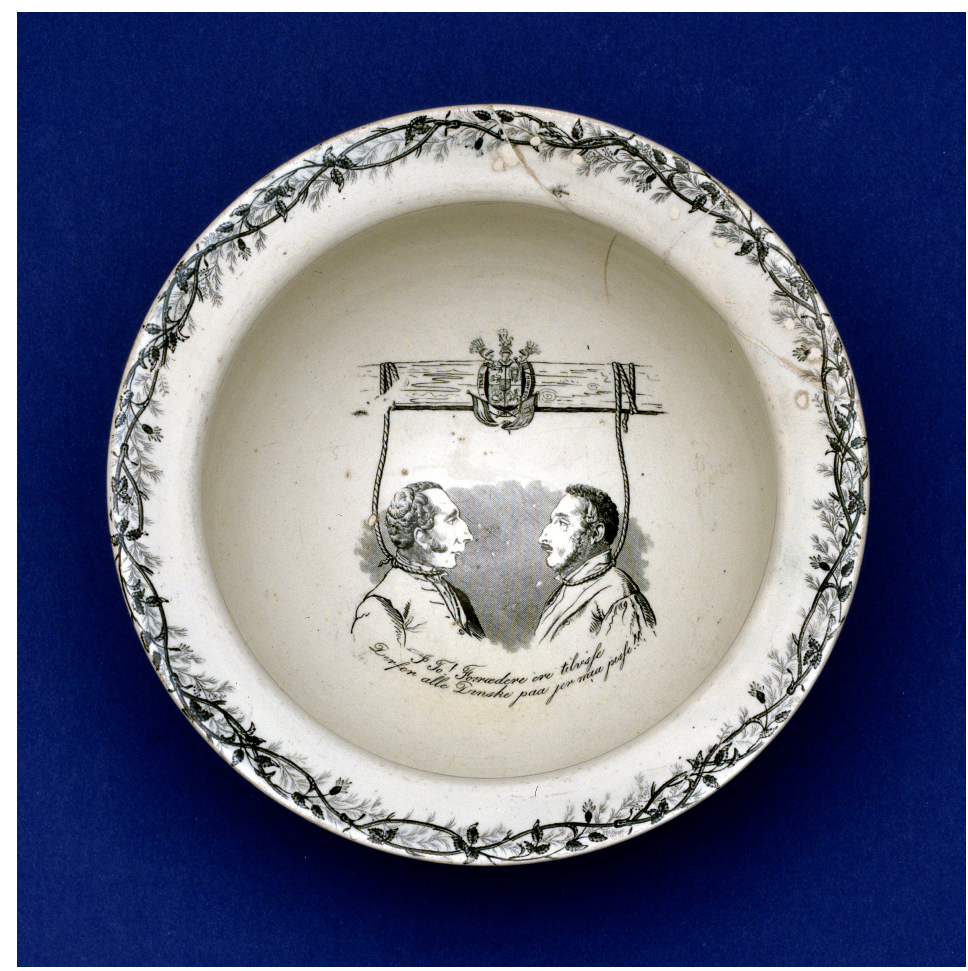

Figur 1 Nattpotte fra treårskrigen (1848-51). De tysksympatiserende hertug Christian August af Augustenborg og hans bror prins Frederik af Nør er avbildet med løkke om halsen. Den politiske innskripsjonen lyder «I To! Forrcedere ere til visse. Derfor alle Danske paa jer maa pisse!!». (C) Nationalmuseet, København

Ludvig XVI skal ha hatt en potte med et portrett av fienden Benjamin Franklin, og engelskmennene laget en potte med Napoleon på. Vanligst var det likevel med tekster som «Use me well and keep me clean / And I'll not tell what I have seen».

\section{Urinundersøkelsen og sansene}

Leger har gjennom tidene brukt både syn, lukte- og smaksans for å undersøke urin. Søren Bloch Laache, professor i indremedisin i Oslo i perioden 1896-1924, bidro til at Norge ble et foregangsland innen urinundersøkelse. Han utga i 1883 en bok om emnet som ble oversatt til tysk, fransk, italiensk og gresk (13-15). 
I Klinisk Urin-Analyse beskrives en omfattende urinunders $ø$ kelse der urinfargen inndeles i ni ulike nyanser. Vanligvis har urin en strågul farge, og fargeintensiteten varierer med mengden vann. Urinen kan av og til ha andre farger. Noen av fargeavvikene skyldes utskilling av fargestoff man har tatt inn via matvarer eller medikamenter (15). Spiser man rødbeter, kan urinen bli rød grunnet det vannløselige fargestoffet betacyanin (16), mens inntak av asparges kan gi urinen et grønnskjær. Ulike sykdomstilstander kan også føre til endring av urinfargen. Urinen kan få en rød farge ved hematuri eller brunlig farge ved ulike former for icterus (15).

Utover på 19oo-tallet ble det påvist at flere medfødte enzymdefekter kan gi urinen uvanlig farge, som svært mørk ved alkaptonuri (17) eller rødlig-fiolett ved varianter av porfyri. Blå bleie-syndromet, også kalt Drummonds syndrom, er en sjelden genetisk tilstand med redusert opptak av tryptofan. Aminosyren blir nedbrutt av bakterier til et indol som absorberes fra tarmen, og ved utskilling i urinen gir det denne et blålig skjær (18).

Lukten av frisk urin beskrives som «eiendommelig aromatisk, ingenlunde ubehagelig» i boken om urinanalyse, og den påvirkes av «så vel nydelsen av medikamentøse som av andre stoffer». Inntak av terpentin skal gi en velkjent fiolduft. En krydret lukt avgis ved inntak av safran eller av apotekermidlet Balsamum copaivae, på norsk kopaivabalsam (15), som ble brukt til sårleging og ved hoste, skjørbuk, kjønnssykdommer og diaré (19). Asparges gir en karakteristisk, stram lukt på urinen, og hvitløk og Valeriana officinalis (legevendelrot) har begge sine typiske dufter $(15,20)$.

Hvis urin blir stående, vil ammoniumionene forvandles til flyktig ammoniakk, som damper av og gir en lite behagelig lukt. For den som ikke skulle ha smakt på urin, er aromaen «bitter, saltaktig», ifølge urinanalyseboken (15). Undersøkelse av urin, inkludert smaken, er viktig også innen ayurveda, læresystemet som danner grunnlaget for tradisjonell indisk medisin. Hvis en medisiner ikke ville smake på urinen selv, kunne han gi oppgaven til en av sine studenter eller la insekter få tilgang til den og observere deres reaksjoner (21).

I gamle sanskrittekster er mange forskjellige typer urin navngitt, blant dem finner vi madhumeha. Her kjenner vi igjen madhu, som er det samme ordet som vi har i «mjød», altså «honning», mens meha er av samme rot som vi har i «miksjon» - og i «mige» (1). Vi forstår umiddelbart at vi har å gjøre med den tilstanden vi i dag bedre kjenner i sin gresk-latinske form som diabetes mellitus (gresk dia = gjennom og bainein = gå, samt latin mel= honning). Tilstanden gir stort volum av urin med søtlig smak, som "går gjennom» pasienten. Ved en annen endokrinologisk tilstand, diabetes insipidus (latin in = ikke og sapio = smaker), er også stort urinvolum (polyuri) karakteristisk. I dette tilfellet smaker imidlertid ikke urinen noe, det vil si - iallfall ikke søtlig (22).

\section{Urin i medisinsk praksis}

Ekskreter og sekreter har i folkemedisinen vært forbundet med magi og brukt til å drive bort demoner, og kroppens utsondringer var en selvfølgelig del også av skolemedisinen frem til slutten av 170o-tallet. Urin er antageligvis blant de eldste legemidlene vi har (9). Urinen skulle være nylatt. Kun den mellomste porsjonen av urinen ble benyttet, akkurat som når vi skal ha en ren urinprøve, såkalt midtstrømsprøve (10).

Urin er blitt brukt utvortes mot en rekke tilstander. Spesielt bra var det mot "skurv» (eksem) og psoriasis. Tyske kjemikere påviste senere at urin har en faktisk effekt, siden den inneholder karbamid, som fremdeles er virkestoff i mange fuktighetskremer (10).

I en episode av TV-serien Venner for livet brenner Monica seg på en brennmanet, hvorpå Chandler tisser på det berørte hudområdet, med lindrende effekt (23). Men denne effekten synes å være en myte. Ved kontakt med en brennmanet vil skylling med saltvann deaktivere neslecellene (nematocystene) som gir hudreaksjonen, mens ferskvann kan bidra til økt frigjøring av toksiner ved å fortynne saltet utenfor cellen. Muligens er det slik at urin, på samme måte som ferskvann, gir økt toksinfrigjøring, siden urin har lavere saltkonsentrasjon enn saltvann $(24,25)$. 
I gamle dager var urin også mye brukt innvortes. Urin ble drukket mot nervesykdommer, og i Hardanger het det derfor: «Drikk mig, gut, so vert du god» (10). Urin skulle også hjelpe mot hoste og astma. En blanding av druebrennevin og pasientens urin og ekskrementer ble brukt som aversjonskur ved drikkfeldighet (10). Urin ble dessuten ansett som virkningsfullt mot kolera, og i sin tid mot den store pesten. Mot innvollsorm kunne man «drikke Mandepis 3 Gange, hver Gang tre Skeer fuld. Saa kryber han ud igjen» (9).

Urin er også blitt anvendt som forebyggende middel, og mange har daglig drukket litt av sin egen urin for å holde seg frisk (9). Det er hevdet at millioner av mennesker verden over den dag i dag bruker sin egen urin innvortes og utvortes. Den tidligere indiske statsministeren Desai skal ha drukket et glass av morgenurinen sin daglig (26). Et tilsvarende litterært eksempel finner vi i Kjell Askildsens novelle Maria (27):

«Maria,» sa jeg, «er det virkelig deg, så godt du ser ut.» «Ja,jeg drikker urin og spiser råkost,» svarte hun. Da måtte jeg le, det var lenge siden sist, tenk at jeg hadde en datter med humor, litt frekk humor til og med, hvem skulle trodd det, det var et godt øyeblikk. Men jeg tok feil, at en aldri blir gammel nok til å kvitte seg med illusjonene. Min datter fikk et måpende uttrykk $i$ ansiktet, og det var som om blikket hennes døde. «Du gjør narr av meg,» sa hun, «men du skulle bare vite.» "Jeg syntes du sa urin,» svarte jeg som sant var. «Urin, ja, jeg er blitt som et annet menneske.» Det tvilte jeg ikke på, det var logisk, en kan da umulig vere det samme mennesket før og etter at en har begynt å drikke urin.

\section{Andre bruksområder}

Utover å bli anvendt som medisin har urin en rekke andre bruksområder. I det gamle Roma ble det tidlig etablert offentlige bassenger for oppsamling av urin. Denne urinen ble solgt til garvere, som brukte den til skinnbearbeiding, og til vaskere, som brukte ammoniakken til rengjøring og bleking av ullstoffet i togaen.

Keiser Vespasian, som var opptatt av å få balanse i de offentlige finansene og få modernisert skattesystemet, innførte en skatt på urinomsetningen fra de offentlige toalettene. Hans sønn og senere keiser Titus syntes dette var et lite smakfullt - eller snarere illeluktende skatteobjekt. Da skal keiseren ha tatt opp en mynt, holdt den under nesen på sønnen og sagt de berømte ord "pecunia non olet» (penger lukter ikke). Dermed ble skatten beholdt. Til minne om den fremsynte keiseren ble de offentlige pissoarene med flere båser i Paris kalt vespasiennes $(12,28)$.

Et annet bruksområde er farging. En beis (fra tysk, egentlig la bite) gjør at et fargestoff «biter seg fast» til det som skal farges og dessuten binder fargestoffet sterkt (29). Typiske beiser er flerverdige metallioner, slik som aluminium, jern, tinn og sink, men både urea og urinsyre har en viss beiseffekt. Urin har derfor vært brukt som beis ved farging av tekstilfibre (30).

Det sies at tekstilkunstneren Hannah Ryggen (1894-1970) hadde en potte stående fremme som hennes gjester ble bedt om å tisse i. Urinen ble blandet med fargestoffet indigo, som i seg selv ikke binder så godt til tekstilfibrene, og ble dermed til potteblått (fig 2) (31,32). I Trondheim må Nidarosdomens karakteristiske irrgrønne tak til stadighet restaureres. Det tar seg dårlig ut at nye takplater skriker imot en med blankt, rødbrunt kobber. For at også de nye platene skal være grønne når de settes på, brukes urin fra ku og hest for å fremskynde irringsprosessen (33). 


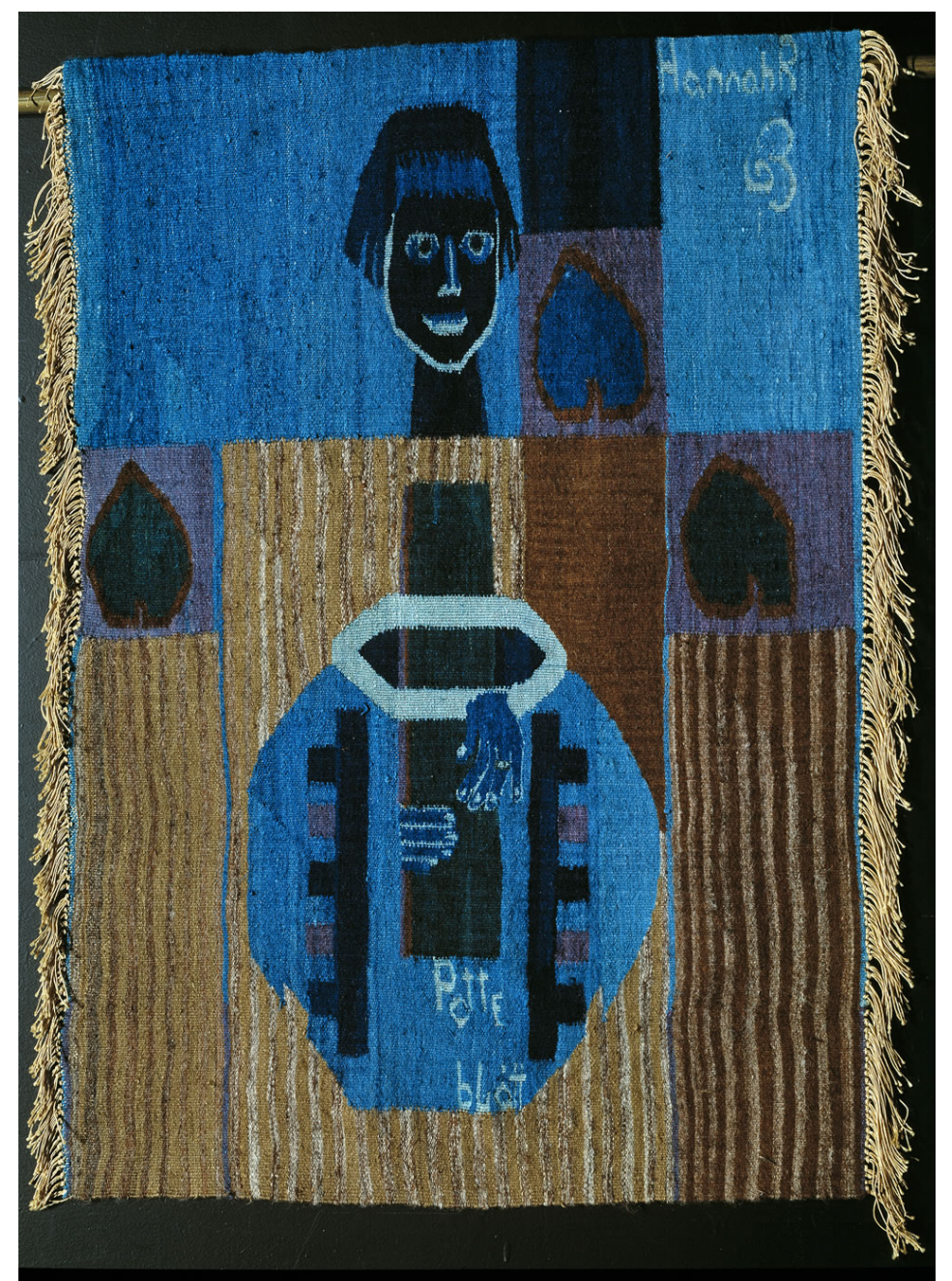

Figur 2 Hannah Ryggens teppe «Potteblått» fra 1963. (C) Hannah Ryggen / BONO 2016

\section{Ren eller uren?}

Urinen har altså vært ansett som både nyttig og unyttig og som ren og uren. Selv om den betraktes som steril, iallfall inntil den når urinrøret, kan nyere studier tyde på at den gjenspeiler urinblærens mikrobiom, og at den også hos friske inneholder et stort antall bakterier. Disse bakteriene dyrkes gjerne ikke rutinemessig ved kliniske mikrobiologiske laboratorier, men bakterie-DNA kan likevel påvises ved polymerasekjedereaksjonstester (34).

Kanskje er det slik at normalt tilstedeværende mikrober i urinen kan være med på å bestemme helsetilstanden i urinveiene, på tilsvarende måte som mikrobene i fordøyelseskanalen og på huden gjør?

\section{LITTERATUR:}

1. Falk H, Torp A. Oppslagsord «mige» og «urin». Etymologisk ordbog over det norske og det danske sprog. Oslo: Bjørn Ringstrøms antikvariat, 1991.

https://www.nb.no/items/341369a2oe37a63f713e182ee4549f24?page=5\&searchTextetymologisk (31.3.2017).

2. Orgland I, Raastad F. Úrkoma. Islandsk-norsk ordbok. Oslo: NKS-forlaget, 1992. https://www.nb.no/items/f28cfdb2277198cd2c020026ao405e97?page=o\&searchTextislandsk-norsk\%2oordbok (31.3.2017).

3. Torp A. Tvag. Nynorsk etymologisk ordbok. Oslo: Bjørn Ringstrøms antikvariat, 1992. https://www.nb.no/nbsok/nb/2f19a6b25c657ebd77de6do404C94030?index=2\#o (31.3.2017).

4. de Caprona Y. Land. Norsk etymologisk ordbok. Oslo: Kagge Forlag, 2013. 
5. Sturluson S. Edda - Gylfaginning og prosafortellingene av Skáldskaparmál. I: Holtsmark A, Helgason J, red. Nordisk filologi - tekster og lærebøger til universitetsbrug. 1. bind. København: Ejnar Munksgaard, 1950: 86.

https://www.nb.no/items/o664b9aofe68115cd86aa7713f65of6o?page=o\&searchTextskaldskaparmal (6.11.2017).

6. Nov. Bokmålsordboka. http://ordbok.uib.no/nov (19.7.2016).

7. Urinere. ordnett.no. Norske synonymer. (19.7.2016).

8. Lens. Bokmålsordboka. http://ordbok.uib.no/lens (19.7.2016).

9. Holck P. Norsk folkemedisin. Oslo: Cappelen, 1996: 66, 110-1, 4.

10. Bjertnæs A. Groblad, meitemark og krutt. Oslo: Gyldendal, 1997: 21, 78, 81, 149-50.

11. Natpotte med billeder af hertug Christian August af Augustenborg og hans bror, prins Frederik af Nør. Pinterest: Nationalmuseet. https://no.pinterest.com/pin/3068o841181451459/ (9.11.2016).

12. Berg A, Ottosen R. Nattstolen og potta. Med hjerte i døra - et bidrag til doens historie. Oslo: Tiden Norsk Forlag, 1988: 42-9.

13. øren_Bloch_Laache. Søren Bloch Laache. https://snl.no/Søren_Bloch_Laache (4.3.2017).

14. Daae LNW, Andersen H, Wien TN. Urinundersøkelser i 2015: Fortsatt aktuelt med mikroskopi. Bioingeniøren 2015; 7: 18 - 20.

15. Laache S. Klinisk Urin-Analyse. 3. utg. VIII-IX, 4-10. Kristiania: Steenske Bogtrykkeri og Forlag, 1900. https://www.nb.no/nbsok/nb/1411e27945a20ae1fb81b85b17fa596d?index=2\#o (31.3.2017).

16. Betacyaniner. https://snl.no/betacyaniner (20.7.2016).

17. La Du BN, Zannoni VG, Laster L et al. The nature of the defect in tyrosine metabolism in alcaptonuria. J Biol Chem 1958; 230: 251 - 6o. [PubMed]

18. Drummond KN, Michael AF, Ulstrom RA et al. The blue diaper syndrome: Familial hypercalcemia with nephrocalcinosis and indicanuria. Am J Med 1964; 37: 928 - 48. [PubMed][CrossRef]

19. Jacobsen G, Hem E, Sigurdsson J. «afgjort, at denne Børnesygdom paa Vestmannø kan forebygges» neonatal tetanus på Vestmannaeyjar. Tidsskr Nor Legeforen 2011; 131: 701 - 6. [PubMed][CrossRef]

20. Pallesen S, Bjorvatn B, Nordhus IH et al. Valeriana som sovemiddel? Tidsskr Nor Lægeforen 2002; 122: 2857 - 9. [PubMed]

21. Magner LN. A History of Medicine. New York: Marcel Dekker, 1992: 41-2.

22. Nørgaard JR, Holmboe K. Diabétes. Anatomiens navne - oprindelse og betydning. 8. utg. Århus: Nyt Nordisk Forlag Arnold Busck, 2005.

23. The One With The Jellyfish. Friends Wiki.

http://friends.wikia.com/wiki/The_One_With_The_Jellyfish (19.7.2016).

24. Tønset KA. Helseskade ved kontakt med brennmaneter. Tidsskr Nor Lægeforen 2007; 13: 1277 - 8.

25. Curtin C. Fact or fiction?: Urinating on a Jellyfish Sting is an Effective Treatment. Scientific American, 2007. http://www.scientificamerican.com/article/fact-or-fiction-urinating/ (19.7.2016).

26. Hörl WH. The medicinal use of urine. Am J Nephrol 1999; 19: 111 - 3. [PubMed][CrossRef]

27. Askildsen K. Maria. Alt som før - noveller i utvalg. Oslo: Forlaget Oktober, 2005:322-3.

29. Levick B. Vespasian. New York: Routledge, 1999.

3o. Beising. https://snl.no/beising (6.11.2017).

31. Nylænd J. Norske plantefargar. Oslo: Det Norske Samlaget, 1976:36.

32. 2015. Hannah Ryggen. https://nbl.snl.no/Hannah_Ryggen (11.9.2015).

33. Ryggen H. Potteblått. http://samling.nasjonalmuseet.no/no/object/NG.M.o2576 (23.10.2016).

34. Årrestad K. Hestepiss farger Domen. nrk.no, 2010.

https://www.nrk.no/trondelag/hestepiss-farger-domen-1.7214999(11.09.2015).

35. Lewis DA, Brown R, Williams J et al. The human urinary microbiome; bacterial DNA in voided urine 
of asymptomatic adults. Front Cell Infect Microbiol 2013; 3: 41. [PubMed][CrossRef]

Publisert: 12. desember 2017. Tidsskr Nor Legeforen. DOI: 10.4045/tidsskr.17.0323

(C) Tidsskrift for Den norske legeforening 2020. Lastet ned fra tidsskriftet.no 